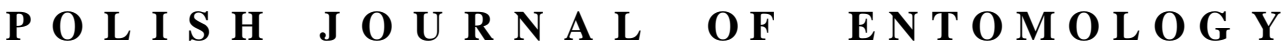

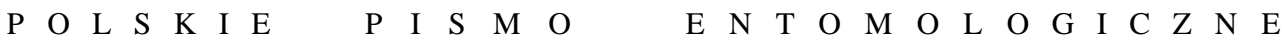

VOL. 85: 13-25

Lublin

30 March 2016

DOI: $10.1515 /$ pjen-2016-0002

\section{Systematics and faunistics of Neotropical Olethreutini, 1: Lobesia GuENÉE, 1845, Ophiorrhabda DiAKONOFF, 1966, Megalota DiAKONOFF, 1966, Eumarozia HEINRICH, 1926, Zomaria HEINRICH, 1926 and Alexiloga MEYRICK, 1922 (Lepidoptera: Tortricidae)

\author{
JÓZEF RAZOWSKI ${ }^{1 *}$, VITOR OSMAR BECKER ${ }^{2}$ \\ ${ }^{1}$ Institute of Systematic and Evolution of Animals, Polish Academy of Sciences, Kraków, \\ 31-016 Sławkowska 17, Poland \\ ${ }^{2}$ Reserve Serra Bonita, P.O. Box 01, 45880 Camacan BA, Brazil
}

\begin{abstract}
Six genera - Lobesia, Ophiorrhabda, Megalota, Eumarozia, Zomaria and Alexiloga are treated, and the following species are described as new: Lobesia uncata sp. n., Eumarozia atrotincta sp. n., and Zomaria dyscrita sp. n. Alexiloga defluxana is removed from the synonymy of A. rubiginosana and four species are redescribed. Statherotis hyeroglypha is transferred to Ophiorrhabda.
\end{abstract}

KEY WORDS: Tortricidae, Olethreutini, Neotropical, new species.

\section{INTRODUCTION}

The present paper is the first in a series of papers dealing with the systematics and geographical distribution of Neotropical Olethreutini. The occurrence of Lobesia GUENÉE, 1845 in the Neotropics is supported by a description of one new species (the preceding species included in this genus are not congeneric). One genus (Ophiorrhabda DIAKONOFF, 1966) was to date only known from the Oriental/Australian region. Although the species described here fits well within the generic diagnosis for Ophiorrhabda, an additional study on its systematic position is needed.

* Corresponding author: Razowski@isez.pan.krakow.pl 
Part 2 of this series (in preparation) relates to Episimus WALSINGHAM, 1891, Omiostola MEYRICK, 1922, and Cosmorrhyncha MEYRICK, 1913.

\section{Acknowledgements}

The authors thank Dr Łukasz PrZYBYŁOWICZ, Artur CZEKAJ, and Witold ZAJDA, Kraków, for taking the photographs and arranging the plates.

\section{MATERIAL}

The specimens examined for this paper were collected by the second author. The types of the newly described species are temporarily housed in the Becker Collection, Camacan, Brazil (VOBC), and will eventually be deposited in one of the Brazilian museums. A few specimens have been kindly donated to the Institute of Systematics and Evolution of Animals, Polish Academy of Sciences, Kraków (ISEA).The numbers cited on the labels of the specimens are the entry numbers in the register book of the VOBC.

Abbreviations used: GS - genitalia slide, NHML - Natural History Museum London (formerly the British Museum (Natural History), WZ - Witold Zajda.

\section{RESULTS}

\section{Lobesia GUENÉE, 1845}

Lobesia GuENÉE, 1845, Annls Soc. Ent. Fr., (2)3: 297. Type species: Asthenia reliquana HÜBNER, [1825] 1816. Europe.

\section{Remarks}

PowELL et al. (1995) catalogued two Neotropical species of Lobesia, both belonging, however, to other genera. The species described below is the first true Neotropical representative of the genus. 


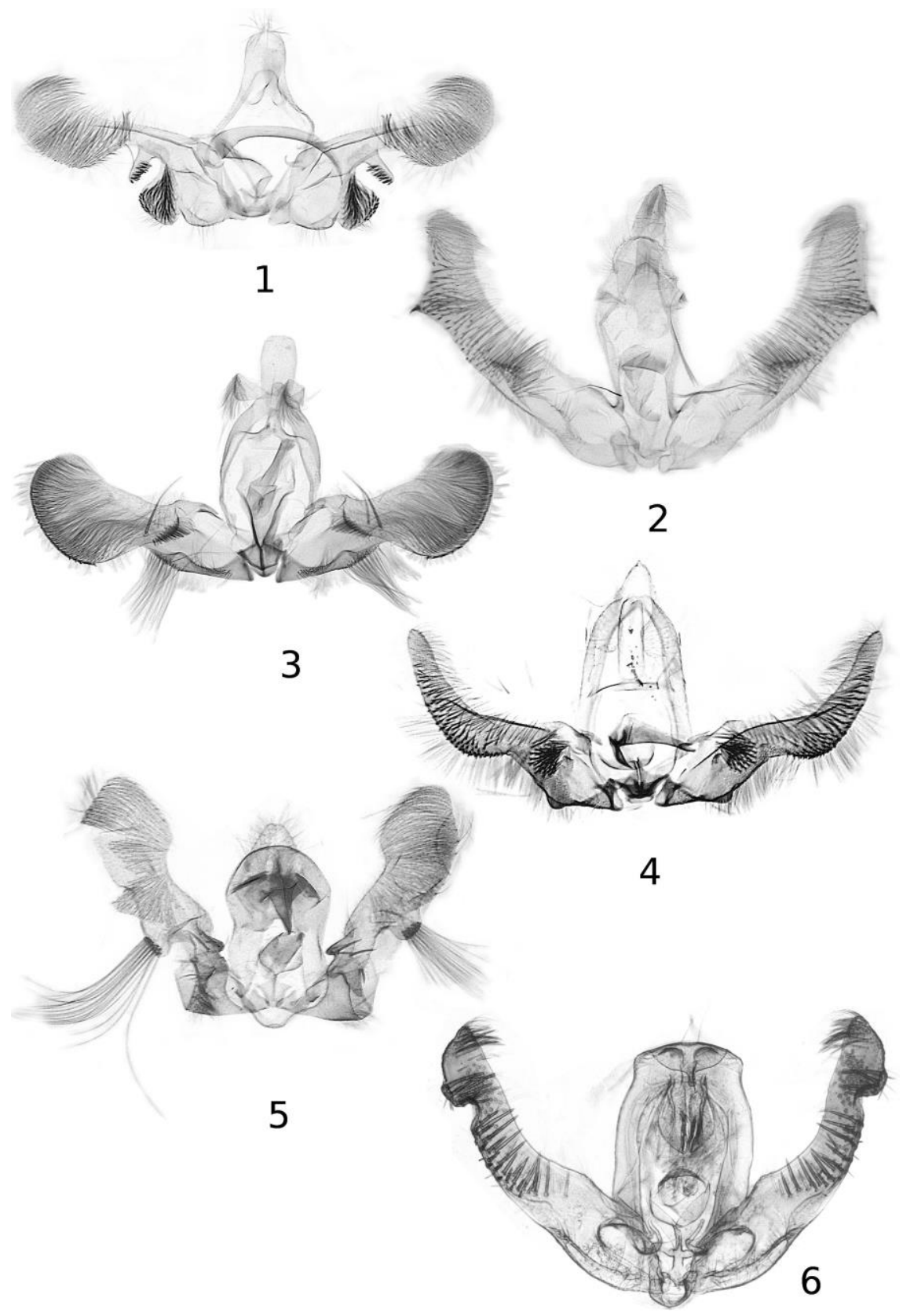

Figs 1-6. Male genitalia: 1 - Lobesia uncata sp. n., holotype; 2 - Ophiorrhabda hyeroglypha RAZOWSKI \& WoJTUSIAK, Santa Catarina, Brazil; 3 - Eumarozia beckeri ClARKE, near Veracruz, Mexico; 4 - Eumarozia atrotincta sp. n., holotype; 5 - Zomaria dystricta sp. n., holotype; 6 - Alexiloga rubiginosana WALKER, holotype. 


\section{Lobesia uncata sp. $\mathbf{n}$.}

(Figs 1, 9, 13)

\section{Diagnosis}

L. uncata is related to L. carduana (BUSCK, 1907) from Maryland, U.S.A. but uncata has a long, curved aedeagus, a broad ventrocaudal lobe of the sacculus, a more median spined process from the ventral incision of the valva, an oval cucullus, and a small, slender uncus.

\section{Description}

Wing span $9.5 \mathrm{~mm}$. Head brownish white, frons whitish; thorax cream brown. Forewing expanding terminad; costa straight; apex and termen convexly rounded. Ground colour in costal and basal areas grey with blackish transverse lines, in dorsomedian part cream with rust suffusions, in terminal third darker with rust and brownish markings; costal strigulae brown and rust; median fascia rust, brown at costa. Cilia brown. Hindwing pale brown; cilia cream.

Variation. Female darker than male with more distinct markings.

Male genitalia (Fig. 1). Uncus small, slender, fused with vestigial socii,basal part of valva broad; ventral incision large with median, spiny process; sacculus weakly convex with large ventrocaudal, densely spined lobe; cucullus rather short, oval; aedeagus long, slender, curved, extending ventroterminally.

Female genitalia (Fig. 9). Sterigma cone-shaped, distinctly expanding proximally, incised in middle posteriorly; antrum sclerite weak; distal part of ductus bursae weakly bent, built of thick membrane; signum absent.

\section{Material}

Holotype male: "Costa Rica, Turrialba 600 m, Vii. 1981, V.O. BECKER Col.; Col. BECKER 46050"; GS 1005 WZ. Paratype female, similar label but Nr of Becker col. 46051; GS 1004 WZ.

\section{Etymology}

The name refers to the presence of an uncus.

\section{Ophiorrhabda DIAKONOFF, 1966}

Ophiorrhabda DiAKONOFF, 1966, Zool. Verh. Leiden, 85: 47. Type-species: Olethreutes ergasima MEYRICK, 1911 from New Guinea. 

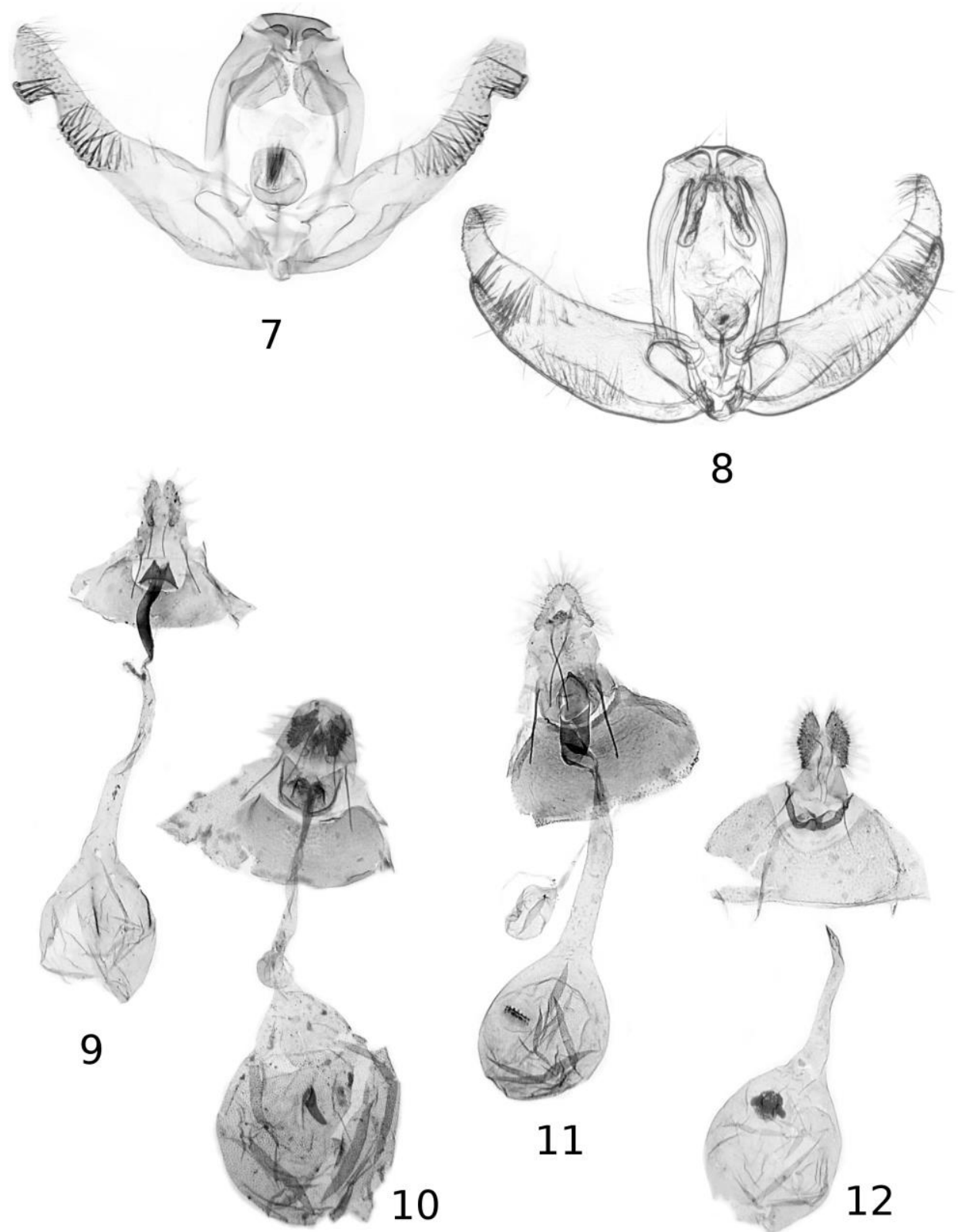

8

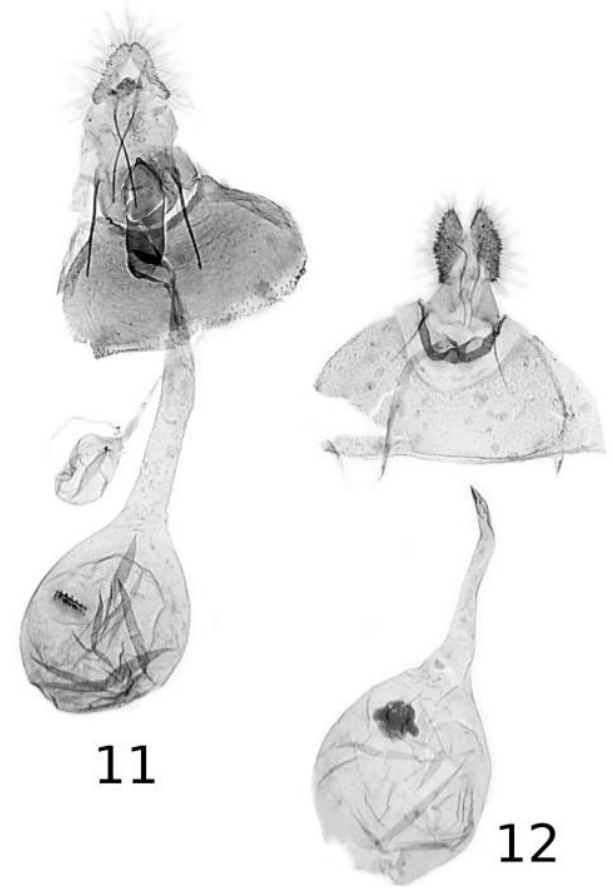

Figs 7-12. Male and female genitalia: 7 - Alexiloga rubiginosana WALKER, Parana, Brazil; 8 - Alexiloga defluxana WALKER, holotype; 9 - Lobesia uncata sp. n., paratype; 10 - Ophiorrhabda hyeroglypha RAZOWSKI \& WOJTUSIAK, Santa Catarina, Brazil; 11 - Megalota submicans (WALSINGHAM), Brazil; 12 - Zomaria dystricta sp. n., paratype. 
Fourteen species belong to Ophiorrhabda; they are distributed chiefly in the OrientalAustralian region (only one species is Palaearctic). The male genitalia of $O$. hyeroglypha (RAZOWSKI \& WOJTUSIAK, 2009) are very similar to those in representatives of Statherotis MEYRICK, 1909 but the female has a single funnel-like signum typical of Ophiorrhabda.

This genus is recorded here as new for the New World.

Ophiorrhabda hyeroglypha (RAZOWSKI \& WOJTUSIAK, 2009), comb. n.

(Figs 2, 10)

Statherotis hyeroglypha RAZOWSKI \& WOJTUSIAK, 2009, Acta zool. cracov., 51B(1-2): 159; type locality: Rio Mashpi, Ecuador.

\section{Description}

Female genitalia (Fig. 10). Sterigma plate-shaped with lateromedian folds at ostium bursae, rounded proximally; sclerite of antrum slender, long; signum with large blade.

\section{Material}

Three males and 1 female from Brazil (Rondonia, Caculandia 140 m, IX. 1991, V.O. BECKER Col; Col. BECKER 96274", GS 924 WZ); 1 male and 2 females labelled from Santa Catarina (Brusque 100 m, 15-20. I. 1983; Col. Nr. 51890, GS 925 WZ). Several specimens from Costa Rica, (Turrialba 600 m, IV. 1973, Nr 37683 and X. 1971 (Nr 35743).

\section{Remarks}

This species was described in Statherotis chiefly on basis of the male genitalia but the newly discovered female is typical of Ophiorrhabda (see the above genus).

The Costa Rica specimens are paler, have a brown-cream forewing ground colour than the Brazilian specimens, but have identical male genitalia.

\section{Distribution}

Ophiorrhabda hyeroglypha is widely distributed as evident from the three known populations: Province of Pichincha, Ecuador (type locality); Santa Catarina, Brazil; and Turrialba, Costa Rica. 

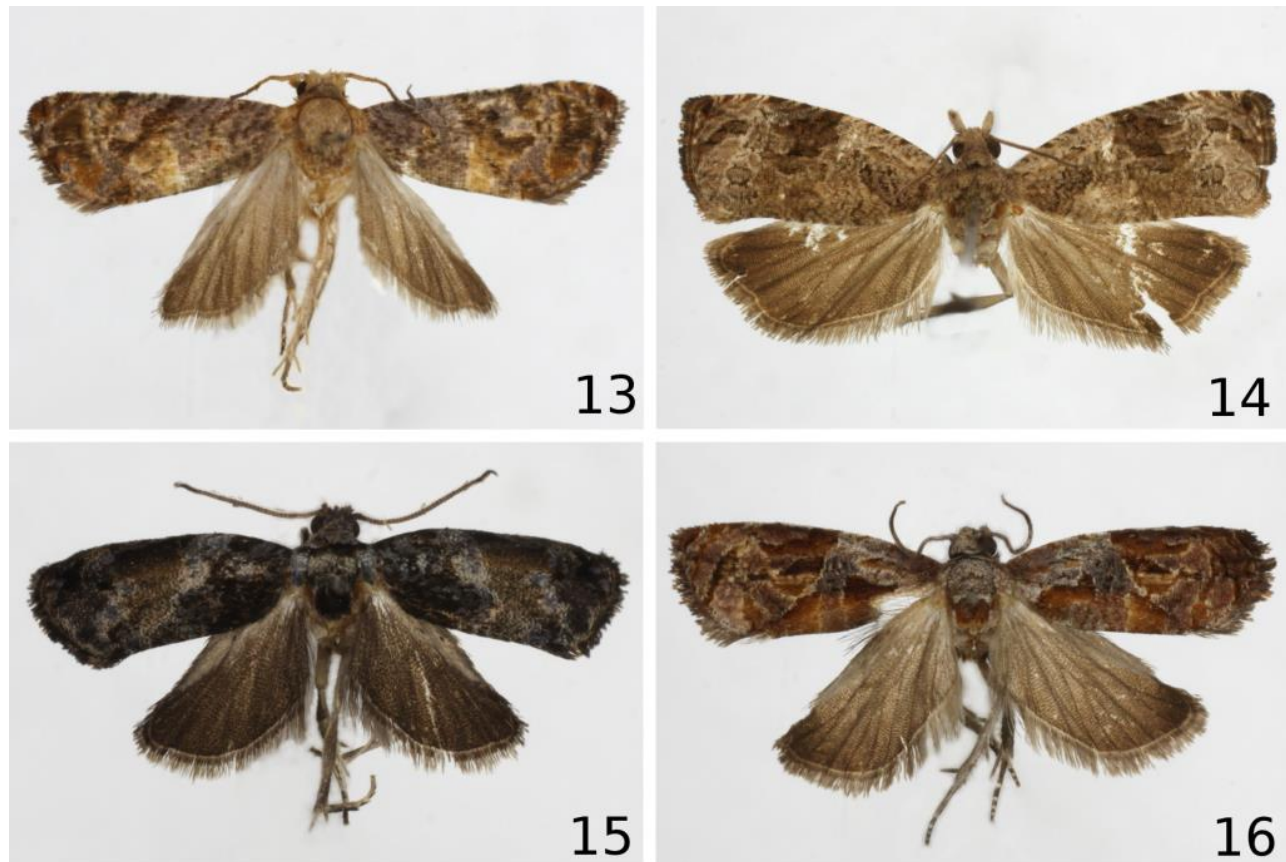

Figs 13-16. Adults: 13 - Lobesia uncata sp. n., holotype; 14 - Megalota submicans (WALSINGHAM), Brazil; 15 - Eumarozia atrotincta sp. n., holotype; 16 - Zomaria dystricta sp. n., holotype.

\section{“Statherotis” sangaica (RAZOWSKI \& WOJTUSIAK, 2009)}

Statherotis sangaica RAZOWSKI \& WOJTUSIAK, 2009, Acta zool. cracov., 51B(1-2): 159; type locality: Via Guamote Macas, Sangay, Morona Santiago, Ecuador.

Material

One male from Ecuador (Maldonado 2200 m, 9-11. I. 1993, V.O. BECKER Col; Col. BECKER 105307; GS 507 WZ).

\section{Distribution}

Known from Ecuador only; it was described from the Province of Morona Santiago from the altitude of $3100 \mathrm{~m}$. 


\section{Remarks}

This species was described in Statherotis on basis of the male genitalia; its facies and the shape of the gnathos and uncus are, however, distinct. Examination of the female genitalia may verify its systematic position. Until then we leave its generic assignment unchanged.

\section{Megalota DIAKONOFF, 1966}

Megalota DiAKonoff, 1966, Zool. Verh. Leiden, 85: 52. Type-species: Polychrosis fallax MEYRICK, 1909, Oriental.

Neotropical Megalota was revised by BROWN (2009); RAZOWSKI \& BECKER (2011) described several new species and provided some remarks.

Megalota ?submicans (WALSINGHAM, 1897)

(Figs 11, 14)

\section{Material}

One male from Brazil (Minas Gerais, Sete Lagoas 720 m, 19.V. 1969, V.O. BECKER Col; Col. BECKER 10689"; GS 499 WZ) and one pair from Rio de Janeiro (Manguratiba 1500 m, 20. I. 1993; Nr 10689; GS $499 \mathrm{WZ}$ and Nr 85723, 694 WZ).

\section{Remarks}

BROWN (2009) did not find any differences between the specimens from the West Indies (terra typica) and Argentina; this was confirmed by RAZOWSKI \& BECKER (2011). Reexamination of the Brazilian specimens allows us to mention the following differences from the West Indies population, although they will require further confirmation: forewings broader with slenderer subterminal fascia; incision of the top of uncus deep; dorsobasal process of valva with additional, lateromedian spines; and terminal part of sacculus with a short row of spines and free termination. Female genitalia as in Fig. 11.

\section{Eumarozia HEINRICH, 1926}

Eumarozia HEINRICH, 1926, Bull. U.S. Natn. Mus., 132: 110; type-species: Grapholitha (Poecilochroma) malachitana ZELLER, 1875, Nearctic.

Eumarozia is known from four New World species, two of which are Neotropical. Recently the Nearctic species, malachitana, was well illustrated by GILLIGAN et al. (2008). 
Eumarozia beckeri CLARKE, 1973

(Fig. 3)

\section{Material}

Twelve specimens from the U.S.A. Virgin Islands (San Thomas 300 m, 25-30. VII. 1987, Nr 67165, GS 1327 WZ); Mexico, Veracruz (Estacion Biologica Los Tuxtlas, 11-16. VI. 1981, Nr 42468, GS 788 WZ); Costa Rica (Turrialba 600 m, VI. 1972, Nr 36718, GS 795; Nr. 3782, GS 793 WZ, 794 WZ); Cuba (Pinar Rio, Sierra Rosario 400 m, 5-15. VI. 1990, Nr 71518, GS $1326 \mathrm{WZ})$.

\section{Distribution}

Eumarozia beckeri was known from Turrialba, Costa Rica; the new data from the Virgin Islands, Mexico (Veracruz), and Cuba suggests that beckeri is widely distributed in Central America and southern Mexico.

\section{Remarks}

To complete the original description (CLARKE 1973) we can add that the socius is triangular, the aedeagus is almost as long as the sacculus, and on the proximal part of the fold there occur chiefly spines, not hairs (Fig. 3). There is also a slight variation in the number of long setae situated dorsally to middle of the neck.

\section{Eumarozia atrotincta sp. n.}

(Figs 4, 16)

\section{Diagnosis}

E. atrotincta is related to E. elaeanthes (MEYRICK, 1927) from Bolivia but atrotincta has blackish markings on the forewing, a large uncus, a protuberance on the caudal corner of the sacculus and a slender cucullus.

\section{Description}

Wing span $10.5 \mathrm{~mm}$. Head brownish, front blackish; thorax grey with weak black marks and whitish grey posterior half of tegula. Forewing slightly expanding terminad; costa and termen weakly convex. Ground colour white-grey with grey suffusions and fine, sparse strigulation; costal strigulae minute, whitish. Markings blackish: basal blotch suffused greywhite; median fascia brownish medially, atrophying dorsally; subterminal fascia small. Cilia blackish. Hindwing brown; cilia slightly paler. 
Male genitalia (Fig. 4). Uncus large with apical prominence; socius broad, lateroposterior; tuba analis long, subscaphium weak; basal part of valva broad; neck short; fold with two longer setae proximally; sacculus straight with well-developed protuberance at the angle; and median lobe anteriorly to strong group of spines; cucullus slender; aedeagus tapering terminad, slender posteriorly.

Female unknown.

\section{Material}

Holotype male; "Brasil: S[ão]P[aulo], Bartioga 5 m, 5. XI. 1985; V.O. BECKER Col; Col. BECKER 99171”; GS 535 WZ.

\section{Etymology}

The specific name refers to the colouration of the forewing; Latin: ater - black, tincta painted.

\section{Zomaria HEINRICH, 1926}

Zomaria HeINRICH, 1926, Bull. U.S. Natn. Mus., 132: 111; type-species: Penthina interruptolineana FERNALD, 1882, Nearctic.

Three North American species have so far been included in Zomaria. Zomaria andromedana (BARNES \& MCDUNNOUGH, 1917) was described from Florida, U.S.A., which suggests that the distribution of the genus may extend farther southwards. This is now confirmed by the discovery of one new species in Cuba.

GILLIGAN et al. (2008) provide a colour figure of the adult of the type species.

\section{Zomaria dyscrita sp. $\mathbf{n}$.}

(Figs 5, 12, 17)

\section{Diagnosis}

Zomaria dyscrita is closely related to Z. interruptolineana (FERNALD, 1882) from the U.S.A. but dyscrita has a broad, wedge-shaped median part of the gnathos, a broad naked process from the middle of the basal part of the valva (in interruptolineana this process is more ventral, slender and densely spined), a slenderer cucullus, and a broad, well-sclerotized fold of the anterolateral edge of the sterigma. 


\section{Description}

Wing span $13 \mathrm{~mm}$. Head and thorax brownish grey, head blackish laterally. Forewing weakly expanding terminad; costa convex; termen weakly convex and oblique. Basal area forming triangular patch of grey ground colour extending to before middle of costa and median fascia; remaining part of base rust brown; median fascia chestnut brown with three darker marks; markings in distal third of wing similarly coloured, weak; dorsum pale rust. Cilia rust brown. Hindwing brownish; cilia similar.

Male genitalia (Fig. 5). Uncus absent; socii tapering terminad; median part of gnathos strong, wedge-shaped; basal part of valva broad, angulate posteriorly with wedge-like process, without any spines; three spines in dorsobasal area; neck of valva slender; cucullus elongateoval with outer proximal lobe armoured with group of long setae; aedeagus short.

Female genitalia (Fig. 12). Sterigma weakly sclerotized posteriorly strengthened by sclerotized ventral and lateral edge, incised medioproximally; antrum sclerite short; signum concave medially with broad proximal and pair of slender lateral lobes.

\section{Material}

Holotype male: "Cuba: Holguin, Pin. Mayari 640 m, VII. 1990, V.O. BECKER Col; Col. BECKER 72041”; GS 1156 WZ. Paratype identically labelled female, GS 1155 WZ.

\section{Etymology}

The name refers to the identification of the moth; Greek: dyscritos - difficult to defeat.

\section{Remarks}

The examined specimens were compared with the illustrations by HEINRICH (1926) and GILLIGAN \& al. (2008).

\section{Alexiloga MEYRICK, 1922}

Alexiloga MeYrick, 1922, Exotic Microlepidoptera, 2: 526. Type-species: Carpocapsa rubiginosana WALKER, 1863, Brazilian.

\section{Remarks}

Two species of Alexiloga described in Carpocapsa TREITSCHKE, 1829 (= Cydia HÜBNER, [1825]) from Amazonas were included in Alexiloga. Carpocapsa defluxana WALKER, 1863 was then incorrectly synonymized with A. rubiginosana (cf. BROWN 2005).

The female genitalia are unknown, so the correct systematic position of this genus is uncertain. The males are characterized by an uncus present, broad rather well sclerotized naked 
socii, and long, slender proximal processes from the inner edges of the pedunculi of the tegumen. The valvae of the two species differ distinctly (as described and illustrated with the species below); the aedeagi are simple, short. The shape and position of the processes of pedunculi are the putative autapomorphies of this genus.

Alexiloga rubiginosana (WALKER, 1863)

(Figs 6,7)

Carpocapsa rubiginosana WALKER, 1863, Specimens lepid. Insects Colln. Br. Mus., 28: 401. Type locality: Ega, Amazonas, Brazil. Coll. NHML.

\section{Description}

Male genitalia (Figs 6, 7). Ventrolateral folds of pedunculi large; processes of pedunculi proximal, slender curved; uncus broad basally, forming small, slender apical process; socius broad, rounded apically with slender basal part, devoid of hairs; valva slender with large basal process; sacculus weakly convex; neck ill-defined; cucullus incised subterminally with distinct spines before and beyond incision and posterior hairy part; fold short; aedeagus short, submembranously connected with subscaphium; bunch of moderately large cornuti present; caulis short.

\section{Material}

One male from Brazil (Paraná, Telemaco Borba, 750 m, 13-19.X. 1995; Col. BECKER 97796; GS 669 WZ.

\section{Distribution}

Known from Brazil: Amazonas and Paraná.

Alexiloga defluxana (WALKER, 1863), bona sp.

(Fig. 8)

Carpocapsa defluxana WALKER, 1863, Specimens lepid. Insects Colln. Br. Mus., 28: 407. Type locality: Ega, Amazonas, Brazil. Coll. NHML.

\section{Description}

Male genitalia (Fig. 8). Uncus elongate, slender basally, weakly incised apically to form pair of rounded lobes; socius broad, rounded apically; pedunculi, basal processes of valvae and 
aedeagus as with preceding species; valva rather short, tapering terminad; sacculus convex with terminal process and spines; fold small; neck absent; terminal part of valva pointed, hairy; aedeagus short.

\section{REFERENCES}

BRown J.W. 2005. World Catalogue of Insects. Vol. 5: Tortricidae (Lepidoptera). Apollo Books, Stenstrup.

BRown J.W. 2009. The discovery of Megalota in the Neotropics, with a revision of the New World species (Lepidoptera: Tortricidae: Olethreutini). Zootaxa 2279: 1-50.

Clarke J.F.G. 1973. The genus Eumarozia HeINRICH (Olethreutidae). Journal of the Lepidopterist's Society 27(4): 268-274.

Gilligan T. M., Wright D.J., Gibson L.D. 2008. Olethreutinae moths of the Midwestern United States. An identification guide. Ohio Biological Survey Bulletin, New Series 16(2): vii + 1-334.

HeINRICH C. 1926. Revision of the North American moths of the subfamilies Laspeyresiinae and Olethreutinae. Bulletin of the United States National Museum 132: 1-126.

Powell J.A., Razowski J., Brown J.W., Brown R.L. 1995. Tortricidae. [in] J. HePPNER (ed.). Atlas of Neotropical Lepidoptera, Vol. 3. Checklist: Part 2. Hyblaeoidea - Pyraloidea - Tortricoidea. Scientific Publishers, Gainesville, 138-157.

RAZOWSKI J., BECKER V.O. 2011. Records and descriptions of Neotropical Megalota DiAKONOFF (Lepidoptera: Tortricidae). Polish Journal of Entomology 80(3): 523-534.

Received: 1 June 2015

Accepted: 17 July 2015 